\title{
An African School for African Americans: Black Demands for Education in Antebellum Boston
}

\author{
ShaVonte’ Mills* (D) \\ Pennsylvania State University \\ ${ }^{\star}$ Corresponding author. Email: skm5577@psu.edu
}

\begin{abstract}
This article examines Black parents' efforts to establish and secure quality education for their children in antebellum Boston, Massachusetts. It situates the African School, a Black-owned cultural institution, within Black nationalist politics and reveals how the schoolhouse became a site of political tension between Black Bostonians and the Boston School Committee. Analyzing petitions, school records, and newspapers, this essay finds that the African School cultivated Black citizenship ideologies that prioritized political activism. This study invites new understandings of the political intersections of education and citizenship, and it illuminates the utility of Black nationalism in antebellum Boston.
\end{abstract}

Keywords: education; citizenship; Black nationalism; African School; antebellum Boston

\section{Introduction}

In 1787 and 1796, many Black residents petitioned Massachusetts's leaders and the city of Boston for a separate school in their town. Prince Hall, a prominent Black civil rights activist who consistently challenged the state to recognize Black freedom and provide quality education, led the self-segregation in public education movement. ${ }^{1}$ Although the state supreme court legally eradicated slavery in 1783 and Boston had thereafter integrated schools, these concerned petitioners believed an autonomous institution would protect their children from white supremacy-in the forms of discrimination and poor education-in public schools. ${ }^{2}$ Prince Hall

ShaVonte' Mills is a $\mathrm{PhD}$ candidate at Pennsylvania State University. She thanks Christina Snyder, Amira Rose Davis, Ellen Stroud, colleagues, and the editorial staff at the History of Education Quarterly for their invaluable feedback.

${ }^{1}$ The author capitalizes "Black" to pay homage to Bostonians who have been for generations "in the lower case." The capitalization also recognizes many Black Bostonians' efforts navigating citizenship and systems of exclusion. The author refrains from capitalizing white to reclaim that power struggle in antebellum Boston. For discussion of this capitalization, see David Lanham and Amy Liu, "Not just a Typographical Change: Why Brookings is Capitalizing Black" (Sept. 12, 2019), https://www.brookings. edu/research/brookingscapitalizesblack/.

${ }^{2}$ The Quock Walker case has been viewed as the impetus that legally ended slavery in Massachusetts. See Joanne Pope Melish, Disowning Slavery: Gradual Emancipation and Race in New England (Ithaca, NY:

(c) 2021 History of Education Society. This is an Open Access article, distributed under the terms of the Creative Commons Attribution licence (http://creativecommons.org/licenses/by/4.0/), which permits unrestricted re-use, distribution, and reproduction in any medium, provided the original work is properly cited. 
and fellow petitioners acknowledged Boston's integrated learning centers but foregrounded the adverse effects of educational inequity. They stated, "Our children cannot enjoy education because they are Black." Activists attested that their "children received no benefit from the free school in the town of Boston," and they feared seeing "their rising offspring in ignorance." 3 The state denied the petitioners' request. In 1796, Black Bostonians submitted a similar petition to local officials with explicit language and reasoning that favored self-segregation. They requested the town provide "a school for themselves" to eliminate "discord and hinderance" in Boston's integrated schools. ${ }^{4}$ Racial discrimination impeded Black Bostonian children's full access to quality educational opportunity. Ultimately, Black Bostonians decided to create a separate, autonomous learning center to distance themselves from their enslaved past and demonstrate their rights as citizens of Boston.

Prince Hall and the petitioners linked equitable educational opportunity with full citizenship. Many Black Bostonians of the early republic defined citizenship as the ability to exercise rights such as petitioning, voting, paying taxes, and receiving access to quality education. ${ }^{5}$ Furthermore, they believed that quality education must take place in a non-discriminatory environment and include subjects beyond rote instruction and penmanship. White society, however, neither ensured quality education for Black children nor recognized Black people's full citizenship as political actors. The petitioners argued that as tax-paying citizens they could list "many instances in which they did not enjoy the privileges of free men." Instead of focusing on voting, housing, or employment discrimination, they emphasized the lack of education as a "great grievance." 6 They also argued that Black students could "become good citizens" in a separate school for Black Bostonians-a non-discriminatory, accessible, and cultural institution. As a result, in 1798 the activists established the African School to serve as an important political site, which cultivated an emerging Black nationalist ideology that linked education and citizenship.

Black nationalist activism is embedded in Boston's African School history, and it developed in complex ways from 1798 to 1850. Racial solidarity, African pride, selfsufficiency, separation, self-determination, and Black emigration are core tenets of

Cornell University Press, 1998). For scholarship that questions this case as a watershed moment for emancipation, see Jared Ross Hardesty, Unfreedom: Slavery and Dependence in Eighteenth-Century Boston (New York: New York University Press, 2018), 175-77.

3"Freedmen Petition for Equal Educational Facilities (1787)," in Equal Protection and the African American Constitutional Experience: A Documentary History, ed. Robert P. Green Jr. (Westport, CT: Greenwood Press, 2000), 38-39.

${ }^{4}$ Prince Hall, "A Copy of a Petition to the Selectmen of the Town of Boston October 4, 1796," in Records of African Lodge No. 459 Boston and Philadelphia, https://www.myfreemasonry.com/threads/1796-petitionof-prince-hall-for-school-for-black-children-in-boston.27414/.

${ }^{5}$ For more extensive research on the precarious nature of Black citizenship in the early republic and antebellum US legal culture, see Martha S. Jones, Birthright Citizens: A History of Race and Rights in Antebellum America (Cambridge: Cambridge University Press, 2018); For information on Black suffrage in the early republic, see Mia Bay, "See Your Declaration Americans!!! Abolitionism, Americanism, and the Revolutionary Tradition in Free Black Politics," in Americanism: New Perspectives on the History of an Ideal, ed Michael Kazin and Joseph A. McCartin (Chapel Hill: University of North Carolina Press, 2006), 24-52.

6"Freedmen Petition for Equal Educational Facilities (1787)." 
Black nationalism. Scholars have characterized Black nationalist activism of the nineteenth and twentieth centuries in myriad ways: as ideology and praxis, conservative and radical, fluid, chaotic, and evolutionary. ${ }^{7}$ Although Black people in antebellum Boston were more likely to identify as Black, African, African American, or colored citizens, their activism for quality education and combating white supremacy embodied early Black nationalist thought. ${ }^{8}$ Black nationalism is the process of creating a separate cultural institution-or a set of institutions-that celebrates and cultivates Black solidarity and African heritage. Black Bostonians created the African School to evade racial discrimination and combat white supremacy. Petitioners utilized the autonomous schoolhouse as a political site to maintain their right to equitable education and make claims for inclusive citizenship. Separatism was not a concerted effort to renounce citizenship; rather, it was a means to redress the unfulfilled promise of egalitarian principles from the American Revolution. ${ }^{9}$

This essay finds that Black Bostonians initially prioritized quality education over integration. The activists established their private cultural learning center, the African School, to publicly combat white supremacy and exert their claim to full citizenship as active political members in antebellum Boston. This paper details nascent Black nationalist politics and Black Bostonians' pursuit of quality education as a strategy to demand citizenship in antebellum Boston. Black Bostonians politicized the schoolhouse and utilized Black nationalism to ensure quality educational opportunity and cultural autonomy. White officials were troubled by the Black community's increasing cultural autonomy and political participation in private and public spaces. White Boston school officials later coopted the African School to legalize second-class education for Black children. This study adds to scholarship that complicates the intersections of education and citizenship whereby schools were a gateway, and often a barrier, to citizenship in the antebellum North. ${ }^{10}$ However, the history of the African School illustrates how antebellum African Americans pursued Black nationalism and US citizenship simultaneously.

Black education and citizenship were largely contingent on local and state regulation. The principle of the natural rights of man, an ideology integral to the American Revolution and the Declaration of Independence, explicitly connected citizenship and

\footnotetext{
${ }^{7}$ Wilson Jeremiah Moses, The Golden Age of Black Nationalism, 1850-1925 (Hamden, CT: Archon Books, 1978); Keisha N. Blain, Set the World on Fire (Philadelphia: University of Pennsylvania Press, 2018); and Haroon Kharem and Eileen M. Hayes, "Early Black Nationalism and the Education Critique," in Black Protest Thought and Education, ed. William H. Watkins (New York: P. Lang, 2005), 67-89.

${ }^{8}$ Black identity in the early republic and antebellum North shifted because white society complicated and denied Black citizenship. See Bay, "See Your Declaration Americans!!!”; Patrick Rael, Black Identity and Black Protest in the Antebellum North (Chapel Hill: University of North Carolina Press, 2002); and Stephen Kantrowitz, More Than Freedom: Fighting for Black Citizenship in a White Republic, 1829-1889 (New York: Penguin Books, 2012), 32-37.

${ }^{9}$ For analysis on Black thought in relation to American nationalism, see Bay, "See Your Declaration Americans!!!”

${ }^{10}$ Kabria Baumgartner, In Pursuit of Knowledge: Black Women and Educational Activism in Antebellum America, Early American Places (New York: New York University Press, 2019); Jones, Birthright Citizens; Kantrowitz, More Than Freedom; and Hilary J. Moss, Schooling Citizens: The Struggle for African American Education in Antebellum America (University of Chicago Press, 2009).
} 
equality. ${ }^{11}$ However, citizenship in the early republic and antebellum North was fraught for free Black communities for two reasons. ${ }^{12}$ On the one hand, legally and politically, the state largely controlled Black people's access to citizenship until the late nineteenth century. ${ }^{13}$ On the other, Black citizenship was volatile because enlightened white men and women did not imagine an integrated post-emancipated society, and promoted segregation as a compromise to end slavery and assuage their guilt regarding the contradictory values outlined in the Declaration of Independence. ${ }^{14}$ After the American Revolution in the 1780s, white religious organizations and philanthropic societies established, financially supported, and generally controlled Black education in northeastern urban centers like New York and Philadelphia. Historian Leslie Harris argues that the New York Manumission Society, in particular, created the African Free School to prepare free Black and enslaved people for citizenship because white members believed freedom did not warrant inclusion in the body politic. ${ }^{15}$ Black parents and students worked alongside New York Manumission Society and Philadelphia's Quakers, and demanded redress when they encountered discrimination or subpar education. ${ }^{16}$ Although enlightened liberals' segregation efforts varied by state, schoolhouses in Boston, Massachusetts, were one of the few integrated and locally supported institutions in the Northeast after Independence and northern emancipation. ${ }^{17}$ However, Black Bostonian activists argued that early Boston's integrated schools were unproductive and discriminatory sites for their children.

Between 1796 and 1840, many Black Bostonians promoted self-determination as a way to become politically active and secure rights for their community, such as the right to quality education. Self-determination, another tenet of Black nationalism, was foundational to the activists' institutions such as the African School, the African Meetinghouse, and the mutual aid organization called the African Society.

\footnotetext{
${ }^{11}$ Douglas Bradburn, The Citizenship Revolution: Politics and the Creation of the American Union, 17741804 (Charlottesville: University of Virginia Press, 2009), 239-40.

${ }^{12}$ Citizenship in the early republic was also complicated for women, small farmers, and Native Americans. See Linda K. Kerber, No Constitutional Right to Be Ladies: Women and the Obligations of Citizenship (New York: Hill and Wang, 1998); Erica Armstrong Dunbar, A Fragile Freedom: African American Women and Emancipation in the Antebellum City (New Haven: Yale University Press, 2008); and Bradburn, The Citizenship Revolution. For a comparison of the legal status of Native Americans and free African Americans, see Nicholas Guyatt, Bind Us Apart: How Enlightened Americans Invented Racial Segregation (New York: Basic Books, 2016).

${ }^{13}$ For analysis of "denizen" as the legal status of free Black communities, see Bradburn, The Citizenship Revolution, 238; For research on legal contention regarding the free Black population's claims to birthright citizenship at the state and federal level in the antebellum US, see Jones, Birthright Citizens, 16-34; and Kantrowitz, More Than Freedom, 37.

${ }^{14}$ Guyatt, Bind Us Apart, 17-36.

${ }^{15}$ The state of New York passed the gradual emancipation act in 1799. Leslie M. Harris, In the Shadow of Slavery: African Americans in New York City, 1626-1863 (Chicago: University of Chicago Press, 2003), 64.

${ }^{16}$ Harris, In the Shadow of Slavery; and Dunbar, A Fragile Freedom, 54-57.

${ }^{17}$ For details about the 1789 Massachusetts Education law, see Christopher M. Span, "Learning in Spite of Opposition: African Americans and Their History of Educational Exclusion in Antebellum America," in Counterpoints 131 (2005), 26-53; For a comparative analysis of northeastern politicians' initial efforts to implement statewide public education, see Carl F. Kaestle, Pillars of the Republic: Common Schools and American Society, 1780-1860 (New York: Hill and Wang, 1983), 10-12.
} 
These institutions valorized African identity and cultural awareness when white society discriminated and demonized it. In this case, what drove the golden age of Black nationalist politics was not solely emigration strategies and critiques of Western modernity, but rather efforts to establish cultural awareness, recognition, political activism, and quality education while combating white supremacy. ${ }^{18}$ Black Bostonians' increasing autonomy and cultural politics caused tension with white school officials who sought to regain control of the school and implement exclusionary practices. This study illustrates that early Black nationalist thought was complicated. Separatism did not necessarily denote complete withdrawal from efforts to secure birthright citizenship after northern emancipation. Rather, the history of the African School provides an entry point to understand ways in which citizenship and Black nationalism coalesced until white school officials coopted this learning center to ultimately legalize segregated education.

\section{The Spirit of Self-Determination: The Formative Years of the African School (1796-1817)}

The Black Bostonians' 1787 petition pressured the Massachusetts state court to acknowledge, respect, and protect Black citizenship through quality educational opportunity. The petitioners' request for state financial support, however, was not met. By 1789 , the state had given local governments control of public education. Although the local school committees were customary before this law, the official transition from state authority over education to municipal control suggests that the state preferred that the local government decide matters about Black education. ${ }^{19}$ For Black Bostonian petitioners in 1787 , this power transition directly affected their access to full citizenship, which was grounded in the protection of their civil rights, particularly their access to quality education. African Americans in the early republic fought for citizenship, belonging, and emancipation in the newly formed United States because they believed they fought for, and were entitled to, the promises of revolutionary politicscitizenship and egalitarian principles. ${ }^{20}$ Therefore, Black Bostonians identified the schoolhouse as a key battleground for both education and citizenship. ${ }^{21}$

On October 4, 1796, Prince Hall and "a number of Black citizens of the town" submitted another petition to local officials explicitly requesting a separate school. Petitioners revealed the town's educational disparity evidenced by the few Black children that the Boston School Committee (BSC) admitted into the integrated public schools. Activists requested the town "assist a number of children who were destitute for the means of common education." Hall suggested that the town provide a "school for themselves" for two reasons. First, to redress the "discord and hinderance" in the integrated schools, and second, to aid Black students in their quest to "become good citizens." The undersigned defined good citizens as "good scholars and viable

\footnotetext{
${ }^{18}$ For scholarship on the conservative traits of Black nationalism, see Moses, The Golden Age of Black Nationalism.

${ }^{19}$ Kaestle, Pillars of the Republic, 9-10.

${ }^{20}$ Bay, "See Your Declarations Americans!!!," 35.

${ }^{21}$ Charles Harris Wesley, Prince Hall: Life and Legacy (Washington, DC: United Supreme Council, Southern Jurisdiction, Prince Hall Affiliation, 1983), 82.
} 
members of the state." ${ }^{22}$ Black Bostonians implied that education was an Americanizing agent well before Horace Mann, the father of universal education, popularized the common school system in the $1830 \mathrm{~s}^{23}$ White religious denominations generally built and financially supported Black schools in New York and Philadelphia. ${ }^{24}$ However, Black Bostonian petitioners explicitly connected citizenship and quality education, and they hoped that their local school committee, not a religious or philanthropic organization, would fund their efforts.

The petitioners of 1787 and 1796 identified themselves as citizens and reasoned that Boston's integrated public schools violated Black children's rights and therefore jeopardized their citizenship status. They simultaneously argued for the city to support their autonomous cultural learning center, which sought to provide quality education and cultivate good citizens. Petitioners connected education to both citizenship and Black nationalist thought. Although the BSC denied the community's request, Black Bostonians' continuous migration to the city's West End bolstered the community's efforts to establish their own school to independently provide quality education for their children. ${ }^{25}$

By the later 1790s, middle-class Black Bostonians like Prince Hall and his son, Primus, had established cultural institutions and frameworks in the northern slope of West End, which attracted other Black Americans searching for community. The West End was the suburban area of Boston that generally attracted wealthy and middle-class Bostonians who wanted distance from the city's urban center. In the 1780s, in the wake of emancipation, Black Bostonians capitalized on their newfound mobility and resided throughout Boston's twelve wards. Much of the Black community worked as employees of shopkeepers, merchants, and, wharfingers. Working-class Black Bostonians typically resided in cheap boardinghouses throughout various wards because of poor wages and job competition with poor white Americans and immigrants. In the early republic, very few Black Bostonians were skilled independent tradesmen. However, by the nineteenth century, occupations like barbering and hairdressing had become important examples of autonomy in the Black community. ${ }^{26}$ In the 1780 s and early 1790 s, an increasing number of Black Bostonians began to collectively reside in or near ward 7, also known as Beacon Hill and West End. Historian Jacqueline Barbara Carr posits that the emergence of cultural institutions such as the African Society, a mutual aid society, in 1796 and the African School in 1798 created a foundation for Black Bostonians'

\footnotetext{
${ }^{22}$ Prince Hall, "A Copy of a Petition to the Selectmen of the Town of Boston October 4, 1796," in Records of African Lodge No. 459 Boston and Philadelphia, https://www.myfreemasonry.com/threads/1796-petitionof-prince-hall-for-school-for-black-children-in-boston.27414/.

${ }^{23}$ Moss, Schooling Citizens.

${ }^{24}$ Harris, In the Shadow of Slavery; for the Quakers' and the Pennsylvania Abolition Society's motives behind supporting Black education, see Dunbar, A Fragile Freedom, 54-55.

${ }^{25}$ Jacqueline Barbara Carr, "A Change 'As Remarkable as the Revolution Itself: Boston's Demographics, 1780-1800,” New England Quarterly 73, no. 4 (Dec. 2000), 583-600.

${ }^{26}$ James Oliver Horton and Lois E. Horton, Black Bostonians: Family Life and Community Struggle in the Antebellum North (New York: Holmes \& Meier, 1979), 36-37; Carr, "A Change 'As Remarkable as the Revolution Itself,"” 599.
} 
migrations from the overcrowded North End to the outskirts of the suburban West End of Boston. ${ }^{27}$

By 1798, Prince Hall and other Black residents had established the African School without financial support from Boston school officials. Despite lack of funds, Black parents persisted in their goal to establish and secure educational opportunities for their children. ${ }^{28}$ Black students gathered at the home of Primus Hall. ${ }^{29}$ The provisional school was in the north slope of Beacon Hill, a central location for Boston's Black community. In the colonial and antebellum periods, class and race divided Beacon Hill-the south slope consisted of wealthy white Bostonians while both working-class and middle-class families resided in the Black community on the north slope. ${ }^{30}$ Soon after Primus Hall received the permit to house the private school in his home, yellow fever forced him to close it that same year. In 1800, Primus reopened the school at home and for two years students were "instructed gratuitously." By 1803, students' attendance had increased but pro bono instruction had decreased. Reverend Jedidiah Morse, a proponent of education, and three other white ministers initially supported the "entire" school. ${ }^{31}$ These ministers wanted to help the Black community extend to those who could not afford subscriptions or school fees. After the first yellow fever outbreak, however, they suggested they would pay a teacher's salary if Black parents could find and rent another schoolroom. Guardians and education activists found a vacant carpenter's shop on Belknap Street and relocated the African School in 1803. For three years, the community paid rent and furnished the school while white ministers paid the classically trained teachers from Harvard. ${ }^{32}$ This arrangement at the carpenter's shop would only be temporary, because Black Bostonians pooled their resources to establish their own social, cultural, political, and intellectual institution.

A local Black church called the African Meetinghouse was a multipurpose cultural center for many Black Bostonians. From 1803 to 1806, Black Bostonians simultaneously maintained their agreement at the carpenter's shop and fundraised to erect this multipurpose Baptist church and schoolroom. Many Black Bostonians withdrew from

\footnotetext{
${ }^{27}$ Carr, "A Change 'As Remarkable as the Revolution Itself," 600.

${ }^{28}$ October 15, 1833, Boston School Committee Minutes. Details of the African-Smith School were collected from Boston School Committee Minutes (1792-1854) and Boston School Committee Loose Papers. Both sources are located at the Boston Public Library. Hereafter, I refer to the Boston School Committee Minutes as BSCM and the Boston School Committee Papers as BSCP.

${ }^{29}$ For examples of Black teachers and community leaders establishing schools for their community in personal spaces see Dunbar, A Fragile Freedom, 57-58.

${ }^{30}$ For demographics of the small Black population in antebellum Boston, see Horton and Horton, Black Bostonians; George A. Levesque, Black Boston: African American Life and Culture in Urban America, 17501860 (New York: Garland Publishing, 1994); Peter R. Knights, The Plain People of Boston, 1830-1860: A Study in City Growth (New York: Oxford University Press, 1971); and Adelaide M. Cromwell, "The Black Presence in the West End of Boston, 1800-1864: A Demographic Map," in Courage and Conscience: Black and White Abolitionists in Boston, ed. Donald M. Jacobs (Bloomington: Indiana University Press, 1993), 155-68.

${ }^{31}$ Jedidiah Morse was from Charlestown, an adjacent town about three miles from Boston, and he supported the African Society in 1808. October 15, 1833, BSCM, 401.

${ }^{32}$ October 15, 1833, BSCM 401; George A. Levesque, "Before Integration: The Forgotten Years of Jim Crow Education in Boston” The Journal of Negro Education 48, no. 2 (Spring, 1979), 113-125.
} 
white churches because of discrimination. ${ }^{33}$ Additionally, Reverend Thomas Paul recognized the need to have a place of worship where the community had opportunities to serve leadership positions in the church and avoid humiliation. ${ }^{34}$ The African Meetinghouse was more than a strategy to defray rent costs. It was also a politically charged site that reflected qualities of Black nationalism: African identity, autonomy, and quality education. Black Bostonians created an independent multifunctional space that embraced their African heritage and ensured quality education for their children. Reverend Thomas Paul and the Black community eventually decided that their independent Black church would serve three purposes: to commune, educate, and house tenants. ${ }^{35}$ The worship hall was located on the first floor and the basement housed the schoolroom and tenant living spaces. Boarding houses were prominent residential options for mobile Black sailors and working-class people in between jobs. To build the independent church and maintain the school, the Black community needed to increase its fundraising revenue.

The African Society spearheaded fundraising campaigns for the African School. The African Society's secretary, Cyrus Vassall, emphasized in an 1808 advertisement that the mutual aid organization had "supported and patronized" the school for "several years." 36 A portion of the organization's \$1.25 monthly membership fee helped maintained the independent school. ${ }^{37}$ In addition to the society's financial support, African Society members like Primus Hall, Fortune Symmes, and Cyrus Vassall increased the number of the African School's sponsors, adding eleven white Bostonian officials to the initial group of four white ministers. Officials such as Abiel Smith, Chief Justice Theophilus Parsons, Lt. Governor William Phillips, and eight others agreed to donate $\$ 100$ each toward the teacher's salary. ${ }^{38}$ Additional donors, however, presented some challenges. The new benefactors had two stipulations: the Black community needed to contribute $\$ 300$ dollars to the school, and "the whole of the schoolroom" should support all Black children. ${ }^{39}$

The white benefactors' initial requests were small yet powerful efforts to exert some control of the private Black school. Generally, white philanthropists in early republic Massachusetts donated money to expand education to poor white and Black children

\footnotetext{
${ }^{33}$ Kantrowitz, More Than Freedom, 20-21.

${ }^{34}$ White Bostonians of an Orthodox church tarred Black Bostonian James Easton's pew to ensure he sat in the back of the church. See Horton and Horton, Black Bostonians, 39-42.

${ }^{35}$ The Boston School Committee's recorded history of the African School emphasizes the connection between the school and the church. It states that the "coloured inhabitants" raised money and "subscribed a considerable sum" to purchase the school room and the church together. October 11, 1833, BSCM.

${ }^{36}$ Jedidiah Morse, A Discourse, Delivered at the African Meeting-House, in Boston, July 14, 1808, in Grateful Celebration of the Abolition of the African Slave-Trade, by the Governments of the United States, Great Britain and Denmark (Boston: Lincoln and Edmands, 1808), 2.

${ }^{37}$ The society's new membership fees increased by one dollar between 1796 and 1798 . Additionally, there was a one-dollar absence fee if members missed meetings and events. These changes suggest increased membership as well as the need for money to support the community. African Society (Boston), Laws of the African Society, Instituted at Boston, anno Domini, 1798 (Boston: Printed for the African Society, 1802), 4 .

${ }^{38}$ October 15, 1833, BSCM.

${ }^{39}$ October 15, 1833, BSCM, 401.
} 
who could not afford school fees. ${ }^{40}$ Prioritizing cultural autonomy in a climate of white philanthropy, the Black Bostonians' version of Black nationalism accommodated white benefactors and teachers who understood the African School's purpose to provide quality education for its children. School activists navigated and negotiated philanthropists' stipulations, keeping in mind their own priorities for benefiting and fortifying the Black community in mind. They raised money among three groups: the community at large, Black sailors, and African Society members. Between 1803 and 1807 , the Black community at large contributed about $\$ 100$. The most mobile population of the community, Black sailors, were the largest contributors. ${ }^{41}$ Black sailors could have contributed more than $\$ 98$ had the Embargo Act of 1807 not affected their earnings. ${ }^{42}$ That year, many Black sailors were unemployed and denied their monthly salary of $\$ 10$ to $\$ 17$ per month. ${ }^{43}$ Still, the Black community raised $\$ 198$ of the $\$ 300$ target goal. The African Society of Boston stepped in and contributed $\$ 200$, which exceeded the target goal. ${ }^{44}$ The Black church and the African Society were not mutually exclusive cultural institutions; rather, they were inextricably linked.

In the African Meetinghouse's nascent years, the church was a prominent site for the African Society and activists to meet and discuss ways to enhance their community and their place in the body politic. Therefore, church autonomy was essential to further developing the community and cultivating Black citizenship ideologies that involved political activism and knowledge production. Adding the African School to the church's basement would place the school within the community's activist tradition - a tradition rooted in Black nationalism, education, emancipation, and the struggle for citizenship. ${ }^{45}$ For example, on April 14, 1807, the African Society met and revamped its rules and regulations in response to the Abolition Act, which legally eradicated the transatlantic slave trade. The organization prioritized knowledge production and enterprise. Members corrected misconceptions of Africans and sought "to collect and diffuse, throughout [the United States], accurate information respecting the natural productions of Africans, and, in general, respecting the agricultural and commercial capacities of the African continent, and the intellectual, moral,

\footnotetext{
${ }^{40}$ Kaestle, Pillars of the Republic, 172.

${ }^{41}$ In the early republic, the Black seafaring community made up the larger part of the Black community in Boston. See W. Jeffrey Bolster, “To Feel Like a Man': Black Seamen in the Northern States, 1800-1860," Journal of American History 76, no. 4 (March 1990), 1173-99, www.jstor.org/stable/2936594.

${ }^{42}$ President Thomas Jefferson executively decided to stop all foreign trade with France and Britain during the Napoleonic War. For sailors navigating the Embargo Act, see Philip G. Swan, "We Are Not Objects of Pity': New York City Sailors and the Embargo of 1807," New York History 99, no. 3/4 (Summer/Fall 2018), 294-330; for the impact of the Embargo on US finances, see J. Van Fenstermaker and John E. Filer, "The U.S. Embargo Act of 1807: Its Impact on New England Money, Banking, and Economic Activity," Economic Inquiry 28, no. 1 (Jan. 1990), 163-84.

${ }^{43}$ US Bureau of Labor Statistics, History of Wages in the United States from Colonial Times to 1928: Bulletin of the United States Bureau of Labor Statistics, No. 604 (Washington, DC: US GPO, October 1929), https://fraser.stlouisfed.org/title/4126, 98.

${ }^{44}$ October 11, 1833, BSCM.

${ }^{45}$ The Hortons have argued that Black Bostonians were a part of two traditions, each rooted in a particular community-Boston (liberty) and African American (justice). See Horton and Horton, Black Bostonians, 2.
} 
and political condition of its inhabitants." 46 Additionally, members wanted to "obtain a knowledge of the principal languages of Africa . . . and reduce them to writing ... so they may facilitate the diffusion of information to the natives of that country." African Society members initiated this communication across the Diaspora because they found it had been "practicable." 47

Newer white donors challenged Black Bostonians' decision to locate the African School in the church basement. Between 1807 and 1808, Black church members, African Society members, and Black parents wanted "part" of the basement to be reserved for the school while white benefactors preferred that the whole space be reserved. The newer white benefactors believed the school's location in part of the church basement left ambiguity regarding the "respective rights of the church and school." ${ }^{48}$ Despite the white philanthropists' discontent, the African School remained tethered to the African Meetinghouse and the African Society and continued to be a site of political possibilities and knowledge. The community did not allow white donors to set boundaries within their autonomous African Meetinghouse. After negotiations, benefactors "consented to accept a part of the basement story for a school room" while the other half was leased for housing. The tenants' rent possibly supported the church ministry and the African School. ${ }^{49}$ Black Bostonians maintained their autonomy and rights to the church and school. They made it clear that white benevolence did not mean they would relinquish control over their institutions.

The African School was a part of a rich protest tradition grounded in cultural politics. The African Meetinghouse was a multipurpose cultural institution that permitted the celebration of African identity and political activism. Although the African Society was a mutual aid organization whose membership consisted of wealthy Black Bostonians, the organization hosted events and celebrations that included and informed non-members. The rules and regulations of the meeting on April 14, 1807 , could have caused white benefactors to be weary of the location and rights of the school. The white benefactors' hesitancy to agree on the church founders' rightful claims concerning the meetinghouse and schoolroom indicates that the benefactors wanted to separate the school from the Black nationalist politics of the church and the African Society that empowered Black Bostonians in terms of their African identity, education, citizenship, leadership, and entrepreneurship.

\section{An African Cornerstone: The African Meetinghouse, the African Society, and the} African School (1817-1824)

Black Bostonian leaders connected the church and the school as a particular site to engage in political activism and social justice. Each year, the week after Independence Day, the African Society organized Abolition Celebrations to commemorate the eradication of the transatlantic slave trade and as a vehicle to continue advocating for universal abolition and quality education. Before 1808, the community's

\footnotetext{
${ }^{46}$ Morse, A Discourse, Delivered at the African Meeting-House, in Boston, 26.

${ }^{47}$ Morse, A Discourse, Delivered at the African Meeting-House, in Boston, 27.

${ }^{48}$ October 15, 1833, BSCM, 401.

${ }^{49}$ October 15, 1833, BSCM, 401.
} 
education politics-creating a more effective space for full freedom and citizenshipwas less evident to white benefactors. However, by July 9, 1817, the African Society overtly connected the utility of the Meetinghouse and its organization with the African School. In preparation for that year's Abolition Celebration, Executive Chairman Primus Hall stated that the purpose of the 11:30 a.m. celebration at the African Meetinghouse was to "give thanks to the Almighty for the success and prosperity of our land, and to give praise to the Author of our being for the distinguished privileges which we enjoy in our liberty, and of the instituted means of grace in a house for public worship for ourselves, and a school for our children." ${ }^{50}$ After Reverend Thomas Paul preached, the society passed a collection plate, the proceeds of which were given to the African School. The plural pronoun "our" in Hall's statement connoted Black ownership of the educational institution and place of worship. Further, he explained a major tenet of Black nationalism: separate cultural institutions to combat white supremacy. However, he did not renounce citizenship. He also solidified the community's rightful claim to that space, which white benefactors had contested in 1807. The annual Abolition Celebration commemorated African identity, autonomy, freedom, citizenship, and education, a celebration that increasingly gained white Bostonians' attention.

Some white Bostonians supported Black Bostonians' autonomous institutions. In 1818, Reverend Thomas Gray, a white minister of the Church of Christ, acknowledged Black Bostonians' interconnected institutions as well as their definitions of freedom and citizenship. He noted that "generous benefactors have allowed" you to educate your children. "You have this convenient place of worship where you may assemble, if you please, with those of your own nation, for the worship of him, in whom all the nations of the earth are blessed." ${ }^{51}$ Like Primus Hall's 1817 statement, Rev. Gray acknowledged the Black community's freedom in ownership, and he accepted the church and society's "nation within a nation" ideology. Similarly, in 1819, white theologian Paul Dean recognized that the free Black population and the enslaved community were capable of being worthy citizens and valuable members of society that could take care of themselves and support their families as well. ${ }^{52}$

Some white Bostonians loathed the Black Bostonians' celebrations and their recognition of African identity, autonomy, education, and citizenship. White Bostonians' disdain for Black education aligned with rising overt opposition for Black education in the United States during the 1820 s and $1830 \mathrm{~s} .{ }^{53}$ Many white Bostonians published broadsides that critiqued and ridiculed the African Society and their annual celebrations. Beyond serving as proof that irate white Bostonians' intended to deride the Black community, the broadsides illustrate the politics and interconnections between the African Society, the African Meetinghouse, and the African School. In a 1821 broadside titled "Grand Bobilition," the author, through a racist caricature in the

\footnotetext{
50“African Celebration," Columbian Centinel (Boston), July 9, 1817, 3.

${ }^{51}$ Thomas Gray, A Sermon, Delivered in Boston, Before the African Society, on the 14th Day of July 1818; the Anniversary of the Abolition of the Slave Trade (Boston: Parmenter and Norton, 1818), 13.

${ }^{52}$ Paul Dean, A Discourse Delivered before the African Society, at Their Meeting-house, in Boston, Massachusetts, on the Abolition of the Slave Trade by the Government of the United States of America (Boston: Nathaniel Coverly, 1819), 8, 11.

${ }^{53}$ Northern white people increasingly opposed Black education because it threatened the social hierarchy. See Baumgartner, In Pursuit of Knowledge, 25.
} 
voice of a member of the Black community, lists "toasts," or opinions, of the different schools in the city, the opinions of the public primary and classical schools contrasting with those of the African School. It reads, "De Primary School-Don't care how much he prime um, if he no snap and go off. De Classical Shool-Don't understand um i hope he find out heself and tell ebery body else. De African School-De hope of Africa, and de glory of Wess Bosson." ${ }^{24}$ Although this racist language and contrast intended to belittle the Black community's understanding of Boston's school system, it reveals two important concepts. First, the irate white Bostonians saw the direct connection between the African School and the African Society. Furthermore, they associated the school with Africa, thereby acknowledging the educational politics rooted in Black nationalism. Second, this broadside's language implies that white Bostonians mocked Black vernacular speech and the African languages that the African Society noted in its mission statement.

The Black community responded to the "spurious account of the Bobablition" broadside of 1821 with a dialogue between two hypothetical friends. In it, Scipio Smilax, an African Society member, and his "fren' Mungo Meanwell" discuss their disbelief in "de white folk" not allowing the "brack man alone when he wish to take comfort" in the "Bobablition" celebration. The two friends seem exhausted and unfazed about white people's inaccurate broadsides:

Mungo: But Scipio, what do dey say in dis year Bobablition? Do dey tell any big lie to dishonor de Shocietee, and bring disgrace upon de members?

Scipio: Why no, Mungo, I don't say as dey do, and one berry goodreason be, dat nobody mind what he say, dey got so use to lie bout de matter. . .

Mungo: Ah, dat jus like um, dey do de same ting lass year-and as de Scripture say de hog go into de mud again after he juss wash herself. . . . Dat juss show what fool dey make of demselves, when dey tink dey know eber so much, and good deal more besides.

Scipio: $\quad$ Yes Mungo, dat all bery true. Dey no tink dey make folks laugh at dem all de time dey try to make um laugh at us. ${ }^{55}$

This part of the dialogue recognizes the white Bostonians' intent to discredit the Black Bostonians' claim to public and private space as well as cultural awareness. Furthermore, the dialogue reverses the magnifying glass onto conniving white Bostonians. The African Society characterizes the white people's actions as ridiculous, unnecessary behavior that neither dishonors the African Society nor its activism. Scipio notes that the offensive broadsides are bad publicity for white Bostonians; instead of dismissing the African Society, white Bostonians' "mischief" spreads across the countryside in Northampton, Pennsylvania. Although the rest of the dialogue does not address the African school or church, the African Society's larger point is that the bogus broadsides did not tarnish the organization's objectives to embrace

\footnotetext{
54"Grand Bobalition, or Great Annibersary Fussible" (Boston: s.n., 1821), Library of Congress, https:// www.loc.gov/item/rbpe.05301100/.

55“"Grand Bobalition, or Great Annibersary Fussible" (Boston: s.n. 1821), Library of Congress, https:// www.loc.gov/item/rbpe.05301100/.
} 
its African identity, redress misconceptions about Africa, and celebrate, privately or publicly, the legal demise of the transatlantic slave trade. Furthermore, Scipio and Mungo reveal that white Bostonians were more uncomfortable with the Black community claiming public space by marching through the streets than with them claiming private space by holding services in the African Meetinghouse. ${ }^{56}$ The Abolition Celebrations were constant reminders of Black autonomy and activism for universal abolition and quality education. For years, white Bostonians' critical broadsides attempted to characterize Black Bostonians as un-American, ignorant, and immoral. ${ }^{57}$ Nonetheless, the African Society and the Black community maintained the autonomy of their school and its educational curriculum and exercised their birthright citizenship as they claimed public and private spaces.

\section{Black Bostonians' Education Politics (1824-1835)}

The African School students received a well-rounded education under the tutelage of the young and ambitious Black educator and abolitionist John Brown Russwurm. The earliest extant record of the African School's curriculum in the Boston School Committee (BSC) minutes dates from March 22, 1824, during Russwurm's tenure as principal. John Brown Russwurm, born in Jamaica and formally educated in Quebec, was the first African American graduate of Bowdoin College and cofounder of the abolitionist newspaper the Freedom Journal. After 1812, the city contributed $\$ 200$ to the African School. ${ }^{58}$ In return for its contribution, the BSC demanded oversight in the form of a subcommittee that documented the Black school's attendance rates and the quality of its instruction. Although the African School was not officially a part of the Boston school system, the School Committee recognized the African School as a primary and grammar school. On one side of the African Meetinghouse basement, the primary school consisted of students ages 4-7 and, on the other side of the basement, students ages 8-13 learned in the grammar school. Russwurm managed to teach and supervise the children despite the wide age range. Furthermore, Russwurm provided instruction in high school subjects and advanced learning to the older students because the community did not have a high school. Unfortunately, BSC subcommittee officials, also known as school examiners, disapproved of Russwurm's pedagogy as well as the students under his tutelage.

The white officials believed Russwurm should limit his curriculum to reading, writing, and rote instruction. The BSC board members, however, voted against the subcommittee, stating that "the Master of the African School [was] authorized to teach in his school any of the languages or any branches of science that are taught in any of the publick schools of this city, and that such of his scholars as are desirous of it, may remain in his school, although they are past the ages allowed in the other

\footnotetext{
${ }^{56}$ It is important to note that African Society members received city permission to march to the African church. The permit highlights the local protection and acknowledgment of Black Bostonians' right to assemble. At the end of this response, the anonymous writer provides a quotation from a newspaper observing that the celebration was peaceful, thus negating the bogus broadside that highlighted tension between white and Black Bostonians.

${ }^{57}$ Weekly Messenger (Boston), July 17, 1817, 640.

${ }^{58}$ October 11, 1833, BSCM.
} 
Grammar and Writing schools of the city." ${ }^{59}$ Russwurm knew classical languages like Latin and Greek. ${ }^{60}$ BSC board members approved Russwurm's pedagogy, which suggests the principal likely taught Latin and natural sciences to advanced students. Russwurm and the students' parents did not allow the city's class distinctions to impede the children from receiving a well-rounded educational experience. During Russwurm's tenure as principal of the African School from 1821 to 1824, Black Bostonians received the school committee's small funds and tolerated limited school board involvement, so long as students received quality education. Despite white involvement in the African School, the Black community fought back to ensure quality education. They were disappointed when the beloved Principal Russwurm left in 1824 to attend Bowdoin College. Still, they hoped that William Bascom, a white minister and former Boston schoolteacher, would be an able successor.

Unfortunately, soon after Principal William Bascom arrived at the African School in 1825, Black parents were displeased with their children's education. Unlike John Russwurm's curricula filled with science, grammar, and diverse languages, Bascom reinforced the limited subjects associated with the local primary schools. In 1829, Black journalist, abolitionist, and business owner David Walker expressed his discontent with white America's school system in his Appeal to the Colored Citizens of the World. Walker revealed that the act of restricting and limiting education for African Americans was not particular to the South. He posited that white people wanted African Americans to remain ignorant in the North as well. Walker pointed out that while Boston's Black youth displayed impressive penmanship, they were not proficient with grammar, because the BSC forbade the teaching of grammar to Black children. ${ }^{61}$ Walker's text suggests that BSC members had wanted John Russwurm to implement simple rote instruction in his curriculum during his tenure as principal. Walker deduced "it [was] a notorious fact that the major part of white Americans tried to keep us [Black Americans] ignorant."62 Echoing Walker, Black parents were outraged with the decline in standards after Russwurm's departure. Black Bostonians simultaneously navigated changes in the quality of education and the colonization scheme that challenged and excluded Black citizenship in the US.

The 1830s proved to be a critical juncture for free Black communities in the nominally free states. On February 10, 1831, white members of the American Colonization Society of Boston formalized their scheme to emigrate the free Black population to Liberia in Africa. Black Bostonian leaders-many of whom were a part of the Black nationalist organizations like the Masonic African Lodge and the African Society-quickly created the Anti-Colonization Committee to combat and stymie that project of white supremacy. The Anti-Colonization Committee and a large

\footnotetext{
${ }^{59}$ As an exception, students as young as three years old and as old as sixteen attended the African School. March 22, 1825, 155, BSCM.

${ }^{60}$ Russwurm enrolled as a junior his first year at Bowdoin College because he was proficient in Latin, Greek, natural sciences, and the humanities. See Winston James, The Struggles of John Brown Russwurm: The Life and Writings of a Pan-Africanist Pioneer, 1799-1851 (New York: New York University Press, 2010), 16.

${ }^{61}$ David Walker, David Walker's Appeal to the Coloured Citizens of the World, ed. Peter P. Hinks (University Park: Pennsylvania State University Press, 2010), 35-36.

${ }^{62}$ Walker, David Walker's Appeal to the Colored Citizens of the World, 36.
} 
number of "the colored citizens of Boston" met at "their school-house" to lay claim to their space, discuss citizenship, and denounce the colonization scheme. They argued that removing "the free colored population" to Africa-a land unknown to them, except through geography texts-would not remove the moral disease of slavery in America. ${ }^{63}$ Black Bostonians emphasized their cultural education but noted that knowledge and cultural recognition negated neither their contemporary claims to state citizenship nor the possibility of securing US citizenship.

Boston's Black Anti-Colonization Committee argued that the colonization scheme was a white supremacist tactic that strengthened slavery and denied Black citizenship. Committee members made their argument by posing this philosophical question: "How can a man be born in two countries at the same time?" Black anticolonizationists stated that their opponents' scheme sought to deny US emancipation and Black citizenship. "We conceive, that the question in view stands in two distinct points-the removal of the free colored population from this country, or the acknowledgement of them as citizens. The former position must be acknowledged, on all sides, a means of perpetuating slavery in our land; the latter, of abolishing it. ${ }^{{ }^{6} 4} \mathrm{By}$ the 1830s, some Black Boston residents sharpened their Black nationalist politics and renounced US citizenship. For example, former African School principals John Russwurm and Prince Saunders emigrated to Liberia and Haiti to cultivate racial solidarity and their African heritage. White colonizationists assumed that Black émigrés supported the scheme. However, Black anti-colonizationists distinguished colonization from Black emigration to "Africa, Hayti, or Upper Canada" as evidence of their freedom movement and political self-determination, because Black emigration did not involve "consent [from] the slaveholding party." ${ }^{\text {" }}$ Black anti-colonizationists dismissed white society's scheme to deny Black citizenship, yet they acknowledged and embraced emigration as an alternative Black nationalist strategy to pursue freedom.

The African School cultivated Black activism, tradition, and quality education; however, Black Bostonian parents believed William Bascom was prejudiced. Black Bostonians were convinced that Principal Bascom did not value Black students after "several" girls confessed that Bascom displayed "improper familiarities" with them. ${ }^{66}$ The BSC encouraged parents whose students attended the city's public schools to hold teachers and officials accountable for their school's character and condition. ${ }^{67}$ Although the African School remained a private institution during Bascom's principalship, Black Bostonians believed they ought to hold the BSC accountable because the city paid Bascom's salary. In 1832, Black parents, particularly Joseph Woodson, petitioned for Principal Bascom's removal on the basis of his misconduct against the young schoolgirls. The petitioners "prayed that the board would take such

\footnotetext{
${ }^{63}$ Robert Roberts and James G. Barbadoes, “A Voice from Boston!,” Liberator (Boston), March 12, 1831, 42. For literature on antebellum Black nationalism, see Rael, Black Identity and Black Protest, 82-117.

${ }^{64}$ Roberts and Barbadoes, "A Voice from Boston!," 2.

${ }^{65}$ Roberts and Barbadoes, "A Voice from Boston!," 2. For the distinction between colonization and emigration, see Jones, Birthright Citizens, 37-38.

${ }^{66}$ Quotations are from the BSC's investigation report. See “African School," November 12, 1833, 405, BSCM.

${ }^{67}$ April 8, 1819, BSCM.
} 
consideration and provide such further security for the moral purity and mental improvement of the coloured children."68 Parents mobilized to demand local officials recognize their children's civil rights as citizens as well as their accessibility to quality education.

White officials reluctantly sent examiners to evaluate the condition of the African School and Bascom's conduct. The examination process dragged on for two years. During that time, the committee found that the African School served two purposes. By day, the school was a learning site for young children, and by night, it was a meeting room, lecture hall, and political site for members of Black intellectual societies, abolitionists, and laypeople. Black Bostonians blurred the lines between private and public space through their social activism. BSC members were frustrated with inconsistent attendance rates, the multipurpose use of the African School, and Black Bostonian parents' discontent against William Bascom.

By November 13, 1832, the BSC enacted a rule to impede Black protests and activism at school, an attempt to separate the school from its protest and communal activist tradition and curricula. ${ }^{69}$ The committee stated, "The African School room shall not be occupied for any other purpose than a public day school, without the consent of the subcommittee of that school." ${ }^{\prime 70}$ The BSC disregarded the Black church's autonomy. Defying this restriction, Black Bostonians continued to congregate at the African School for lectures and speeches covering topics like higher education and abolition. Eight months later, on September 14, 1833, Maria Stewart-an abolitionist, women's activist, and one of the church's first woman lecturers-gave her farewell address in the African School room. The following week, on September 28, abolitionists held a memorial for British abolitionist William Wilberforce in the African School. ${ }^{71}$ While Wilberforce's memorial took place in the schoolroom, the Adelphic Union hosted a "Monthly Concert of Prayer for the abolition of slavery and the amelioration of the colored people" that took place in the African Meetinghouse sanctuary. ${ }^{72}$ Black Bostonians continued to view education as a hands-on communal experience that combated racial subjection, discrimination, and injustice.

Black Bostonian parents and education activists consistently agitated and pressured the BSC to remove Principal Bascom. On November 12, 1833, committee member G. W. Blagden reported that, after the BSC's two-year investigation, there was no evidence of Bascom's misconduct with schoolgirls. Three girls testified against Bascom, but their accounts were omitted because "other witnesses. . . declared

\footnotetext{
68"Woodson against Master of African School," January 1, 1832, BSCM, 399; "Woodson," October 15, 1833, BSCM, 401.

${ }^{69}$ During Reconstruction, Black churches created schools to gain control of their communities' educational opportunity. White missionaries and church members often interfered to separate the two as a means to weaken Black autonomy and bolster white control over education, see Heather Andrea Williams, Self-Taught: African American Education in Slavery and Freedom (Chapel Hill: University of North Carolina Press, 2005), 100-102.

${ }^{70}$ November 13, 1832, BSCM, 303.

71 “Multiple News Items," Liberator (Boston), September 14, 1833, 147; “Multiple News Items," Liberator (Boston), September 28, 1833, 155.

72“Multiple News Items," Liberator (Boston), September 28, 1833, 155.
} 
each of them to be of bad character." ${ }^{73}$ Although the examining committee did not state what were the girls' bad characteristics, the BSC acquitted Bascom, demonstrating they refused to honor the Black Bostonian parents' initial petition requesting the state to further secure their children's educational rights and livelihood. Furthermore, Bascom's white privilege trumped the three Black girls' encounter with his abuse; the BSC was more invested in the Black girls' degrees of morality than white male immorality.

This disappointing verdict did not waver Black Bostonian education activists' commitment to protect their children's educational opportunity and rights. Shortly after Bascom's acquittal, petitioners also "charged the teacher with criminal neglect of the school and want of interest [disinterest] in its welfare." 74 On January 1 and Feb 11, 1834, hairdresser James G. Barbados submitted petitions against Bascom to the BSC. Barbados reported that he saw Bascom leave a brothel during school hours. ${ }^{75}$ Following the elderly leader's testimony, the BSC slowly addressed Black education activists' discontent. Three months later, in April 1834, the committee reported the school to be in a "depressed condition and thinly attended," which, they believed, "conferred very limited benefits on the class of persons for whom it was designed." The school examiner attributed the school's thin attendance to a boycott by parents and students. Parents had used the petitions and boycott as leveraging strategies to ensure the city maintained quality education for their children. Although the committee was not convinced that the prejudice against Bascom had "any just foundation," it acknowledged that Black Bostonians wanted a principal they "generally favored." By April 1834, the BSC had voted to remove Bascom from the African School and replaced him with the generally favored abolitionist Abner Forbes to appease Black parents and prevent tensions between the Black community and white officials. ${ }^{77}$

Parents and education activists requested public financial support for the independent African School despite the contention between the School Committee and Black parents. Most parents were displeased with the public school system's strategies to limit Black education. The African School room was overcrowded, and it needed a new building. The parents' request did not mean they would relinquish control of their school. As a result, the process of incorporating a private institution as a public one was complicated and contentious. It became more evident that Black Bostonians and the BSC possessed different meanings of the utility of education and the importance of Black education. Black education activists wanted to use the school as a site for community building, political participation, and quality education that included well-rounded curricula in a non-discriminatory environment. The BSC, in contrast, used the school as an entry point to condone and enforce second-class education.

\footnotetext{
${ }^{73}$ November 12,1833 , BSCM, 405.

${ }^{74}$ November 12, 1833, BSCM, 405.

75 "Barbados against the Master of the African School," January 21, 1834, BSCM, 412.

${ }^{76}$ April 7, 1834, BSCM, 421.

${ }^{77}$ April 7, 1834, BSCM, 421-22.
} 


\section{The Smith School for Black Bostonians: Contentious Education Politics (1835-1850)}

After much deliberation, BSC members agreed to the request for a new school building for the sake of the students' health and development. ${ }^{78}$ According to an announcement in the abolitionist newspaper the Liberator published November 2, 1833, "the Mayor communicated a report to the School Committee, recommending the erection of an African School, in a more central situation, and ask[ed] for an appropriation for that purpose."79 The committee's emphasis on moving the school to a central location reveals their motive to geographically distinguish the school as public property and further separate students from their protest tradition. The committee voted to financially support the African School and renamed it the Smith School in honor of the late Abiel Smith, a white philanthropist and the biggest financial contributor to Black education in Boston. The BSC's encroaching involvement in Black education challenged the Black curricula, which had emphasized advanced education, racial solidarity, leadership training, and advocacy for full freedom. The BSC's discussions of controlling and centralizing Black education exposes the latent turf war between local officials and Black autonomy.

Relocation was the white officials' third attempt to control the African School and Black education. In 1807, philanthropists had disagreed with the decision to locate the African School in the building's basement, and in 1832, the BSC had banned social gatherings in the schoolroom. The BSC relocated the newly constructed three-story Smith School five feet away from the African Meetinghouse. This attempt at establishing control directly challenged Black autonomy, and the new school's location was a visible reminder. By "centralizing the situation," the mayor and school committee members sought to socially control and neutralize the school as city property and begin the process of state-supported second-class education. ${ }^{80}$ In doing so, the white politicians and committee members sought to undermine Black educational politics that embraced Black nationalism and separatism as a means to combat white supremacy and ensure quality education.

Judge William Minot's paternalistic address at the Smith School's opening on March 3,1835 , reveals elements of social control and an attempt to subvert the community's education politics. The committee believed that the school's lack of attendance at the time reflected a lack of parenting at home. Minot incorporated the BSC's concern into his speech, emphasizing the parents' role in investing in their children's education, and he continuously encouraged the parents to regularly send their children to school. Furthermore, Minot linked education, citizenship, and emancipation to good character. He argued that Black Bostonians could "improve [their] condition, rank, and force the world to acknowledge [their] claims to equality" if parents and students "cultivated virtues of industry, temperance, veracity. . . and obedience to the laws." More broadly, Black northerners' good behavior would "afford powerful arguments in favor of

\footnotetext{
${ }^{78}$ By 1833, school committee officials linked environmental conditions to children's intellectual, moral, and physical development. See this report, "School houses," BSCM, 378-83.

${ }^{79}$ The Liberator editor printed the school announcement in the miscellaneous column. "At a meeting of the Mayor and Aldermen on Monday," Liberator (Boston), November 2, 1833, 176.

${ }^{80}$ “At a meeting of the Mayor and Aldermen on Monday," 176.
} 
abolition." Judge Minot demanded that in return for access to public education, Black parents and students needed to follow the dictates of a white male-dominated local government. Minot negated the initial utility of Black education politics, which sought to use the school as a respite from white supremacy and provide an example of quality education as well as full freedom and citizenship. ${ }^{81}$

School examiners evaluated the students' performance through the lens of a BSC-inflected education politics that stressed morality and respectability. A school examiner detailed Black children's characteristics to articulate why the Black school would be unequal to its white counterparts. On June 26,1835 , just three months after the school reopened in its new location, the examiner reported that Black students were in "absence of domestic discipline, want of early instruction" and displayed "habits of idleness, and extreme irregularity of attendance." He stated that the children's bad characteristics was an "obvious" reason why the BSC should not "expect. . . the school to equal the other grammar schools in the city." However, the surveyor was slightly hopeful that the rapport the new teacher, Abner Forbes, had with Boston's abolitionist and Black communities would cause a "remarkable transition" in the school. ${ }^{82}$ The examiner hoped "vacant seats would be filled; the truant and gambler would become attentive. . and the brawler and ungovernable [would] lay aside their oaths. ${ }^{133} \mathrm{He}$ implicitly characterized parents as misguided and explicitly labeled Black children as uncontrollable, inattentive, and uninterested in education.

The examiner described Black students and the possibility of equal education from a reformative perspective. He noted that it was the students' societal issues that made the Black school inferior to the white public schools. The examiner suggested that the Black school could be "proficient and excellent" like its white counterparts so long as the Black community subscribed to respectability politics. ${ }^{84}$ The school examiner and the BSC put the onus on the Black community to be respectable, attentive, and compliant at school, which revealed a formative articulation of the "separate but equal" ideology. In other words, the segregated Smith School had the opportunity to be nominally equal to the white public schools so long as the Black community was compliant and respectable. Black Bostonian parents, however, did not concede to the state's education politics.

\footnotetext{
${ }^{81}$ William Minot, Mr. Minot's Address: Delivered at the Dedication of the Smith School House in Belknap Street, March 3, 1835, to Which Are Added a Few Friendly Suggestions to the Colored People in Boston (Boston: Webster and Southard, 1835). 6; The latter half of the pamphlet featured remarks from an unknown author that provided parenting suggestions and broadly contextualized Minot's point on the utility of education. Minot, Mr. Minot's Address, 12.

82“Grammar Schools Annual Examination," August 1835, BSCP. Abner Forbes was well respected and involved in the Black community. He was one of many managers affiliated with William Lloyd Garrison's interracial abolitionist group, the New England Anti-Slavery Society. Before his principalship, Forbes guest lectured for the Adelphic Union and attended some of the community meetings in the African Meetinghouse and School. See Stephen Kendrick and Paul Kendrick, Sarah's Long Walk: The Free Blacks of Boston and How Their Struggle for Equality Changed America (Boston: Beacon Press, 2004), 80-83.

83“Grammar Schools Annual Examination," August 1835, BSCP.

84"Grammar Schools Annual Examination," August 1835, BSCP.
} 
During Abner Forbes's tenure as principal of the Smith School (1835-1844), Black Bostonian education activists continued to cultivate their Black nationalist education curricula. Despite being geographically separated from the Black protest tradition it had enjoyed in that church basement, the Black community continued to congregate at and around the schoolroom to disseminate knowledge and train leaders. On August 7, 1838, Forbes informed the BSC examiner that 100 out of 211 students were absent that day because they were attending a community celebration for British West India's emancipation. ${ }^{85}$ Here, much like they had with the African Society's Abolition Celebration thirty years earlier, many Black Bostonians were connecting community activism and history with education. Although the celebration did not occur in its traditional location, the African schoolhouse, a hundred students were exposed to a Black nationalist curriculum that was rooted in cultural expression and the valorizing of African identity when white supremacy demonized it. While some gatherings occurred outside the Black schoolroom, others did not. On October 3, 1842, the Adelphic Union (AU) held free "Knowledge Is Power" lectures at the Smith School room. Forbes sold fifty-cent season tickets to the AU's monthly debates at the Smith School room, a bold move by the principal since it flouted the BSC's ban on events that were not school-related or school-approved. ${ }^{86}$ His connection with the $\mathrm{AU}$ was a sign of his unwavering involvement in the Black community as an abolitionist that Black Bostonians trusted. AU members reclaimed their intellectual space as well as their cultural and political traditions when they held events at the Smith School. However, the community's reclamation of their Black nationalist curriculum-rooted in combating racism, activism, and intellectual and cultural expression-did not override the BSC's and Forbes's belief that Black Bostonians and the school were inferior.

As an 1843 report by Forbes to the BSC reveals, it was at this time that he showed himself a discriminatory and negligent administrator. Around early May in 1844, Black Bostonian parents and education activists found Forbes to be a racist, negligent, and violent principal. Parents argued that Forbes implemented "unusual punishment." According to a report in the Liberator, "He feruled a girl on the back of the hand, feruled the boys on the soles of their feet-compelled them to stand in a constrained posture-pinched, and pulled their hair and ears." 87 Additionally, Forbes lost parents' trust after he reported to the BSC that they demonstrated little interest in their children's education. ${ }^{88}$ Forbes negated Black Bostonians' rich activist tradition as well as the historical importance of quality education in the community. Historians speculate that Forbes retaliated against the Black community because he found his task of reforming the school exhausting and irritating. ${ }^{89}$ Concerned parents

\footnotetext{
${ }^{85}$ August 7, 1838, BSCP. In 1838, the British Empire eradicated the apprenticeship system that had subjected Afro-Jamaicans to servitude and maintained the sugarcane industry. See Thomas C. Holt, The Problem of Freedom: Race, Labor, and Politics in Jamaica and Britain, 1832-1938 (Baltimore: Johns Hopkins University, 1992).

${ }^{86}$ "Multiple Classified Advertisements," Liberator (Boston), September 16, 1842, 147; “Adelphic Union Library Association," Liberator (Boston), September 23, 1842, 151.

87 "Report." Liberator, August 2, 1844, 122.

${ }^{88}$ Forbes, "School Committee Semi-Annual Report, 1843," BSCP.

${ }^{89}$ Kendrick and Kendrick, Sarah's Long Walk, 80-81.
} 
felt that Forbes's behavior and his description of the school and the community was unacceptable. Petitioning the BSC to address Forbes's conduct in 1844, parents gave four reasons why he should be removed from the school: (1) "the nature, degree, and manner of punishment; (2) his language and deportment against parents and students; (3) negligence; (4) expressing and entertaining opinions unfavorable to the natural intellectual capabilities of the colored people as a race." From May 11 to 18, BSC examiners interrogated forty-six witnesses. Of that total, the Black community had a small representation; only seven parents and six students testified against Forbes. ${ }^{90}$ In early June 1844, the BSC acquitted Forbes despite a plethora of evidence against him and scant relevant testimonies that supported him. Outraged, many parents created their own examining committee, and on July 25,1844 , they detailed their findings for "fellow citizens" in the local newspaper, the Atlas. The "Committee of Parents and Others Interested in the Smith School" (CPO) detailed portions of the evidence that the BSC dismissed. The CPO found that Forbes inflicted unusual punishment on students as he feruled their hands and feet "without mercy." One young girl was so traumatized after Forbes disciplined her that she voluntarily admitted herself into a juvenile correction center for three months. After family members found the young girl, she said she preferred to stay at the center rather than attend the Smith School with Mr. Forbes. ${ }^{91}$

Most Black Bostonians believed that Abner Forbes had demeaned and abused Black students. At the trial, Forbes presented his editorial from August 18, 1842 as evidence of impartiality regarding his "views on the colored race." Forbes "believed there [was] no human art or science, if they can enjoy facilities suited to their natures." ${ }^{2}$ Offended, the CPO asked, "What does [this] mean? Why add the words suited to their natures? Why is the word 'their' in italics?"93 Parents were concerned that Forbes's argument justified separate and inferior education for Black students. Furthermore, the CPO believed Forbes's sentiment would simultaneously devalue Black cultural politics and hamper the existing leverage the community had in ensuring the city supported quality Black education. The CPO's concluding statement acknowledged the role public education played in community uplift. The committee believed the "facilities afforded for the education of our children have... improved the character and standing of the colored people in Boston. Anything which tends to lessen our eagerness to enjoy our advantages of a good education would be a great public evil." This statement echoed the Black Bostonian education activists' petition of 1787 , which connected quality education to citizenship and full freedom. The CPO's 1844 report noted that the city had recognized and supported quality

\footnotetext{
${ }^{90}$ The other thirty-one witnesses that defended Forbes were a mixture of other principals and former students from neighboring schools, police officers, clergymen, musical instructors, and teachers. For the quotation, the summary of the May interrogation, and the various witnesses, see "Report of a Committee of Parents and Others Interested in the Smith School, in Boston, Relative to the Official Conduct of Mr. Abner Forbes, Master of Said School," Atlas (Boston), July 25, 1844, 1.

91"Report of a Committee of Parents and Others Interested in the Smith School," 1.

${ }^{92}$ The Teacher, Boston Courier, August 18, 1842, 2. Clarkson, the author of the editorial, is Forbes's alleged penname or alias.

93"Report of a Committee of Parents and Others Interested in the Smith School," 1.
} 
education for Black children. However, Abner Forbes's principalship jeopardized Black Bostonians' security in citizenship and quality education.

Abner Forbes's acquittal revealed that the BSC promoted "exclusive" education that denied Black children access to quality education. Forbes's scandal fractured the Black community's strategy for reforming education and securing civil rights. ${ }^{94}$ Soon after the verdict, Black parents and education activists appealed to the BSC to integrate the schools. One of the activists was AU president John T. Hilton, who, according to an article in the Atlas, petitioned the BSC to "abolish the separate schools for colored children, and asked for the rights and privileges extended to other citizens in respect to the common school system-viz the right to send our children to other schools" within the district. ${ }^{95}$ The BSC quickly denied the petition and stated that the separate school would continue. On June 28, 1844, Hilton "recommended parents withdraw their children from the exclusive school, [because] it was established in contravention of that equality of privileges which is the vital principle of the school system of Massachusetts." Hilton noted that the BSC, not Black Bostonians, deviated from the African School's tradition and original objectives when it established the Smith School. His distinction crucially differentiated the BSC's second-class education for Black students from the Black Bostonians' politics of inclusive quality education, which fostered Black cultural expression and advanced learning. Hilton and the petitioners also argued that a segregated school "at the public charge" was contrary to state law. ${ }^{96}$ Black Bostonians leveraged the state to support quality education for Black children. Petitioners hoped the BSC would extend Black children's educational access to all public schools. The city denied the community's demands for inclusive public education. In this sense, a public segregated school codified second-class education, which coopted earlier efforts on the part of Black Bostonians to establish a separate school as a respite from white supremacy. Hilton and his supporters believed that boycotting the Smith School would force the city to grapple with their contradictory policies. However, not all Black Bostonians believed desegregating Boston's public schools was the best strategy to secure full citizenship and freedom.

By 1848, as the school desegregation boycott strengthened, Thomas Paul Smith had emerged as the Black community's most prominent advocate for maintaining the Smith School. On August 2, 1848, Smith submitted a petition to the BSC and requested it appoint his uncle, Thomas Paul Jr., as the Smith School's principal. Fittingly, Thomas Paul Jr. was the son of Reverend Thomas Paul, the founder of the community's first Black Baptist church, the African Meetinghouse. ${ }^{97}$ Smith believed that the only way to ensure both quality education and Black nationalist politics was to have an all-Black educational staff. However, John T. Hilton, Robert Morris, and other integrationists disagreed with Smith and sought to maintain the boycott. They believed a Black principal would curtail their momentum to force

\footnotetext{
${ }^{94}$ Integration and separation emerged as two factions of Black nationalism in the 1840s. See Watkins, Black Protest Thought and Education, 69.

95“Meeting of Colured [sic] Citizens," Atlas, June 28, 1844, 2.

96"Meeting of Colured [sic] Citizens," 2.

${ }^{97}$ August 2, 1848, BSCP; August 10, 1848, BSCP.
} 
the BSC to close the school and integrate. ${ }^{98}$ Integrationists believed that the Smith School would only provide a subpar education. Documentary evidence suggests they may have been right. Drawing on the grammar examinations of Smith School students uncovered from this period, historian Hilary J. Moss concludes that their poor and failing results suggest that Black students generally received inadequate education compared to white students. ${ }^{99}$

One day after Smith submitted his petition supporting the appointment of Thomas Paul as principal, nearly half of the signees submitted a new petition to remove their names. ${ }^{100}$ The Liberator considered Thomas P. Smith's reasoning a "personal controversy," and added that Black Bostonians' position on the school "changed as often as chameleons changed their color." ${ }^{\text {101 }}$ Black Bostonians all agreed on the need for firstrate education, but could not agree on how best to achieve that goal.

On October 5, 1849, Smith tried to vindicate his position for maintaining the Smith School. He argued that he approved of the idea of integration and recognized parents' right to choose an integrated education for their children. However, Smith disapproved of eradicating a cultural institution that originally provided a haven against white supremacy and provided a framework for political participation, autonomy, and quality education. ${ }^{102}$ Furthermore, Smith argued that "from beginning to end," the Black school's history was not rooted in "exclusiveness." White people, he reasoned, were not excluded from Black institutions. Rather, "exclusiveness is on the other side of the house; it originated among the white portion of the community and them only." ${ }^{103}$ Smith's distinction implies that for like-minded Black Bostonians, separate institutions provided an alternate space and strategy that shielded them from aspects of white supremacy and promoted a more efficient model of citizenship and freedom. Smith opposed losing this cultural institution of the community and spelled out what he believed would be the consequences of desegregation. ${ }^{104}$ Furthermore, abolishing the Smith School would dismantle Black Bostonians' politics.

Horace Mann and other white Bostonians spearheaded the common school movement to amplify a national American identity and discourage divisive religious and ethnic loyalties. ${ }^{105}$ School reformers used the common school system as an "Americanizing agent" that merged public schooling and citizenship and denied Black children's citizenship and their access to equal quality education. ${ }^{106}$ Smith

\footnotetext{
${ }^{98}$ Moss, "The Tarring and Feathering of Thomas Paul Smith: Common Schools, Revolutionary Memory, and the Crisis of Black Citizenship in Antebellum Boston,” New England Quarterly 80, no. 2 (June 2007), 218-41.

${ }^{99}$ Moss, "The Tarring and Feathering of Thomas Paul Smith," 227.

${ }^{100}$ August 2, 1848, BSCP; August 10, 1848, BSCP.

101“To Correspondents," Liberator, September 28, 1849, 154. For more information on the intra-racial tension over integration, see Moss, "The Tarring and Feathering of Thomas Paul Smith."

${ }^{102}$ Thomas P. Smith, “Mr. Garrison," Liberator (Boston), October 5, 1849, 160. For Smith's arguments about the school's cultural relevance and origins, see Thomas P. Smith, An Address Delivered before the Colored Citizens in Opposition to the Abolition of Colored Schools (Boston: Bela March, 1850), 6-7.

${ }^{103}$ Thomas P. Smith, "Mr. Garrison," 160.

${ }^{104}$ Moss, “The Tarring and Feathering of Thomas Paul Smith," 228.

${ }^{105}$ Moss, Schooling Citizens, 4; Kaestle, Pillars of the Republic.

${ }^{106}$ Moss, "The Tarring and Feathering of Thomas Paul Smith," 224.
} 
advised his pro-integration peers to dismantle white supremacy-that is, the exclusive common school system-not their historical and cultural school or the Black community's politics. His emphasis on cultural preservation demonstrates that Black nationalism was both a cultural and political project.

Despite the historical, cultural, and political arguments that Smith made, integrationists believed that the BSC coopted Black political space as a way to codify public segregation. The BSC repeatedly denied the protestors' integration demands from 1844 and 1849. In late 1850, an African School graduate, Benjamin E. Roberts, sued Massachusetts for denying his five-year-old daughter access to the neighboring white school and forcing her to walk five miles to the segregated Smith School. Chief Justice Lemuel Shaw of the state supreme court ruled against Roberts, reasoning that the BSC, not the court, had the authority and power to decide educational matters. He also pointed out the BSC already divided schools according to certain attributes, separating writing and grammar schools by gender and an advanced Latin School by academic excellence. Shaw concluded that according to the logic of this system, schools could be segregated by race as well. In other words, a school for Black children was more a matter of classification than discrimination. Furthermore, he argued that "prejudice, if it exists, is not created by law, and probably cannot be changed by law."107 By extension, the Smith School and its second-class education that reflected white prejudice was not created by law. As historians Stephen and Paul Kendrick have noted, the phrasing of "not created by law" abjured the court's responsibility to ensure "equality before the law." ${ }^{108}$ It laid the groundwork for the separate but equal doctrine in Plessy v. Ferguson, and it was a massive hurdle attorney Thurgood Marshall needed to overcome in the famous case of Brown v. Board of Education of Topeka in $1954 .^{109}$

\section{Conclusion}

Rooted in a protest tradition, the African School served multiple purposes. It emerged as a fortified cultural institution alongside the African Meetinghouse and the African Society. The school exposed children and the community to organizational lectures and annual Abolition Celebrations where people gathered to discuss citizenship and celebrate local abolition as well as strategize for universal abolition. Although Black Bostonians hosted their cultural celebrations and lectures in the privately owned institution, they also occupied public space. As Black Bostonians paraded and gathered in the streets, they publicly critiqued slavery, American colonialization schemes, and limited citizenship. This rich protest tradition and cultural politics, along with the increasingly blurred lines between private and public space, troubled many white Bostonians.

As white benefactors and the BSC witnessed the formation of overt Black nationalist politics and connections between the Black church, the African Society, and the

\footnotetext{
${ }^{107}$ Kendrick and Kendrick, Sarah's Long Walk, 177.

${ }^{108}$ Kendrick and Kendrick, Sarah's Long Walk, 177.

${ }^{109}$ Kendrick and Kendrick, Sarah's Long Walk, 177. Also see Leonard W. Levy and Harlan B. Philips, "The Roberts Case: Source of the 'Separate but Equal' Doctrine," American Historical Review 56, no. 3 (April 1951), 510-18.
} 
school, they increased their involvement and surveillance of the African School. The BSC sought to separate the school geographically and ideologically from the Black community's institutions-the church and the mutual aid society. This, in turn, divided the Black community, which debated the best path to education and citizenship. Despite significant opposition from Black integrationists, the newly redubbed Smith School survived. Between 1835 and 1850, however, the school's new location, name, and non-Black leadership negatively affected children's access to quality education. Furthermore, these changes-Principal Bascom's misconduct, growing Black opposition, the BSC sanctioning separate but equal education-and the implications of such changes required the Black community to reevaluate the debate between selfsegregation and integration. While the African School initially served as a site of Black empowerment, white people sought to undermine its mission. Ultimately, most Black Bostonians supported integration as a strategy to ensure education reform and redress second-class education and citizenship.

The history of the African School extends the history of Black independent education initiatives back to the earliest days of the US republic. Self-determining Black schools and institutions rooted in Black nationalist thought are often associated with the Black Power era. ${ }^{110}$ These twentieth-century schools embodied separation, refuge, political activism against white supremacy, economic self-sufficiency, heritage, and political self-determination outside the legal and financial authority of whitedominated society. However, the history of the African School reveals earlier attempts to combat white supremacy, secure quality education, maintain autonomy, and build racial solidarity without renouncing citizenship. This study adds to scholarship that contextualizes the complexities of Black nationalism within education and citizenship movements in the early republic and the antebellum Northeast. The history of the African School in Boston invites scholars to further investigate the complex possibilities in which Black people in the antebellum free states navigated both Black nationalist thought and US citizenship.

\footnotetext{
${ }^{110}$ Russell Rickford, We Are an African People: Independent Education, Black Power, and the Radical Imagination (New York: Oxford University Press, 2016).
}

Cite this article: ShaVonte' Mills, "An African School for African Americans: Black Demands for Education in Antebellum Boston," History of Education Quarterly 61, no. 4 (November 2021), 478-502. https://doi.org/10.1017/heq.2021.38. 